\title{
A Method for the Iodination of Insulin and its Binding to Dissociated Mouse Mammary Cells
}

\author{
YASUKO INAGAKI AND KAORU KOHMOTO \\ Department of Animal Breeding, Faculty of Agriculture \\ University of Tokyo, Bunkyo-ku, Tokyo 113
}

\begin{abstract}
The iodination of insulin was accomplished by a modification of the lactoperoxidase method. The use of a low concentration of hydrogen peroxide $(1.5 \mathrm{ng} / \mu l)$ followed by Sephadex gel filtration and purification on a cellulose column yielded iodoinsulin with an activity equal to that of native insulin in stimulation of glucose oxidation in rat epididymal fat cells and with high specific binding to collagenase-dissociated mouse mammary cells from pregnant and lactating mice. Other hormones tested did not displace the binding. Analysis of displacement curves and Scatchard plots suggests that both the affinity and the number of sites for insulin binding differ between pregnant and lactating mammary cells.
\end{abstract}

The mammary gland is one of the possible targets of insulin action (Juergens et al., 1965). Insulin receptors exist in mammary glands from pregnant and lactating mice (O'Keefe and Cuatrecasas, 1974; Apostolova et al., 1976) and in mammary adenocarcinoma from rats (Harmon and Hilf, 1976). However, nonspecific binding of iodoinsulin to mammary cells was abnormally high compared with that to fat cells (Cuatrecasas, 1974), likely as a result of either damage to the insulin by iodination or to the mammary cells during the dissociation process. Availability of iodoinsulin and mammary cells with intact biological activity seemed necessary for further investigation into insulin-receptor interaction in the mammary gland. Several methods have been developed to iodinate insulin (Freychet et al., 1971; Hamlin and Arquilla, 1974; Gliemann et al., 1979). We have been iodinating prolactin under

Received August 27, 1980. mild conditions using lactoperoxidase (Sakai et al., 1975). The iodoprolactin showed high specific binding activity to mammary epithelial cells dissociated with collagenase (Enami et al., 1973). These methods were modified for studies on insulin binding to mammary glands, and are described herein along with the bioactivity of the iodoinsulin and its binding to mammary cells.

\section{Materials and Methods}

\section{lodination of insulin}

Unless otherwise stated, $0.05 \mathrm{M}$ phosphate buffer ( $\mathrm{pH}$ 6.9) was used to dissolve reagents mentioned in this subsection. To $1.0 \mathrm{mCi}$ carrier-free $\mathrm{Na}^{125} \mathrm{I}$ (New England Nuclear Corp.) in $20 \mu l 0.1 \mathrm{~N} \mathrm{NaOH}$, were added $25 \mu l 0.5 \mathrm{M}$ phosphate buffer ( $\mathrm{pH}$ 6.9), 10 $\mu l$ lactoperoxidase $(10 \mu \mathrm{g}$, Calbiochem), $8 \mu l$ bovine crystalline insulin ( $4 \mu \mathrm{g}$, Organon, $23.8 \mathrm{IU} / \mathrm{mg}$ ), and $10 \mu l \mathrm{H}_{2} \mathrm{O}_{2}(15 \mathrm{ng})$ in sequence. The same amount of $\mathrm{H}_{2} \mathrm{O}_{2}$ was added 1,3 and $6 \mathrm{~min}$ after the first addition of $\mathrm{H}_{2} \mathrm{O}_{2}$. The mixture was diluted with $500 \mu l$ phosphate buffer 10 min after the first addition of $\mathrm{H}_{2} \mathrm{O}_{2}$. The insulin-bound iodine was separated from unbound iodine by gel filtration on a Sephadex 
G-50 column $(1 \times 18 \mathrm{~cm})$ which had been pretreated with $1.5 \%$ bovine serum albumin (BSA, Fraction V) and equilibrated with the elution buffer $(0.05 \mathrm{M}$ sodium phosphate). Eluates $(1.0-\mathrm{m} l)$ were collected in tubes containing $0.2 \mathrm{ml}$ of $1.5 \%$ BSA. The first peak of radioactivity was further purified on a cellulose column (Whatman CF-11, $1 \times 2 \mathrm{~cm}$ ) as described by Kabuto et al. (1977). Iodinated insulin was eluted with $4 \mathrm{ml}$ of $7 \%$ BSA in $0.1 \mathrm{M}$ tris- $\mathrm{HCl}$ buffer $(\mathrm{pH}$ 7.6) at $30^{\circ} \mathrm{C}$ after the column was washed with $15 \mathrm{ml}$ of $0.1 \%$ BSA in $0.02 \mathrm{M}$ phosphate buffer ( $\mathrm{pH} 8.0$ ), and stored at $-20^{\circ} \mathrm{C}$ until used.

\section{Specific activity of iodinated insulin}

The specific activity of iodinated insulin after gel filtration was calculated by the method of Greenwood et al. (1963). To correct the change in specific activity during purification on a cellulose column by preferential absorption of diiodoinsulin to cellulose, iodinated insulins before and after purification were digested with Pronase $\mathbf{P}$ (Kaken Chemicals Ltd., Tokyo) at $37^{\circ} \mathrm{C}$ for $5 \mathrm{hr}$, and analyzed for the ratio of diiodotyrosine to monoiodotyrosine by paper chromatography with 1-butanol, acetic acid and water (20:3: 7 by volume). Before purification, iodoinsulin contained $7.5 \%$ of diiodoinsulin; almost no diiodoinsulin $(1.6 \%)$ was detected after purification. The specific activity of purified iodinated insulin was estimated to be $90 \%$ of that of iodinated insulin before purification, based on the efficiency of iodination $(55 \%)$ and the radioactivity ratio of diiodotyrosine to monoiodotyrosine.

\section{Acrylamide gel electrophoresis}

Mixtures of iodinated insulin (about $8000 \mathrm{cpm}$ ) and $10 \mu \mathrm{g}$ native insulin were subjected to analytical disc electrophoresis on $10 \%$ acrylamide gel at $\mathrm{pH}$ 9.5. Gels were stained with $1 \%$ amidoblack 10B, and cut into $2-\mathrm{mm}$ segments after destaining. The radioactivity of each segment was counted in a welltype scintillation counter (Packard Model 5110).

\section{Bioactivity of iodinated insulin}

The epididymal fat pads from two male Wistar rats were incubated in Krebs-Ringer bicarbonate buffer containing $1 \%$ dialyzed BSA (KRB-1\%BSA) and $0.2 \%$ collagenase (type I, Sigma Chemicals) at $37^{\circ} \mathrm{C}$ for $45 \mathrm{~min}$ (Rodbell, 1964; Kasuga et al., 1977). Isolated fat cells $\left(2 \times 10^{5}\right.$ cells $)$ were incubated in $1 \mathrm{ml}$ KRB-0.25\%BSA containing $0.2 \mu \mathrm{Ci}$ [U-14 $\mathrm{C}$ ]glucose (334 $\mathrm{mCi} / \mathrm{mmole}$, The Radiochemical Centre, U.K.), 300 nmole of unlabelled glucose, and 0.25 to $4 \mathrm{ng}$ iodinated or native insulin. The concentration of iodinated insulin was calculated from the specific activity. After incubation for $2 \mathrm{hr}, 0.5 \mathrm{~m} l 8 \mathrm{~N} \mathrm{H}_{2} \mathrm{SO}_{4}$ was added to the incubation mixture, and $\mathrm{CO}_{2}$ released was trapped in $0.25 \mathrm{ml}$ Hyamine $10 \mathrm{X}$ at $37^{\circ} \mathrm{C}$. The radioactivity was counted in a liquid scintilla- tion counter (Aloka, Model LSC-651, Tokyo) with a counting efficiency of $85 \%$.

\section{Binding activity of iodinated insulin to mam- mary cell}

Two- to three-month-old pregnant and lactating KA mice were used. The days of plug observation and parturition were counted as days $\mathbf{0}$ of pregnancy and lactation, respectively. Mammary epithelial cells dissociated with collagenase (Enami et al., 1973; Sakai et al., 1978) were incubated in M199-0.25\%BSA $\left(3 \times 10^{6}\right.$ cells $\left./ 0.4 \mathrm{~m} l\right)$ with iodinated insulin (100000 $\mathrm{cpm}$ ) and native insulin ( 0 to $64 \mathrm{ng}$ ) at room temperature for $45 \mathrm{~min}$ and then centrifuged at $12000 \times \mathrm{g}$ for $5 \mathrm{sec}$ in an Eppendorf centrifuge (Model 5412). The pellet was rinsed twice with $1 \mathrm{ml} 0.01 \mathrm{M}$ phosphosaline-0.25\% BSA ( $\mathrm{pH}$ 7.4). Nonspecific binding was determined by incubation in the presence of $5 \mu \mathrm{g}$ native insulin. Our observation had shown that the specific binding reached equilibrium in $40 \mathrm{~min}$ and remained on a plateau at least up to $60 \mathrm{~min}$. Specific bindings at 10, 20 and 30 min were 61,89 and $97 \%$ of the maximum.

Cross reaction was determined with other hormones: ACTH (Armour), ovine prolactin (NIH-PS12), glucagon (Novo), pancreozymin (Boots) $(4 \mu \mathrm{g}$ each for the hormones mentioned above), secretin (Boots), EGF and NGF (5 $\mu \mathrm{g}$ each for these three hormones).

\section{Results}

Table 1 shows the results of iodinations in which various amounts of insulin (1 to $5 \mu \mathrm{g})$ and $\mathrm{Na}^{125} \mathrm{I}(0.5$ to $1 \mathrm{mCi})$ were used. The specific activity of iodinated insulin increased in proportion to the ratio of iodine to insulin. When $1 \mathrm{mCi} \mathrm{Na} \mathrm{Na}^{125} \mathrm{I}$ and $4 \mu \mathrm{g}$ insulin were used, the specific activity was $200 \pm 4 \mu \mathrm{Ci} / \mu \mathrm{g}$ (mean $\pm \mathrm{SE}$ ) in 5 experiments. Fig. 1 shows the effect of $\mathrm{H}_{2} \mathrm{O}_{2}$ concentration on the incorporation of radioactivity into insulin. Seventy-four percent of the radioactivity was incorporated into insulin when $1.5 \mathrm{ng} / \mu l \mathrm{H}_{2} \mathrm{O}_{2}$ was used. The iodination mixture was gel-filtered on Sephadex G-50, and separated into two radioactive peaks. The first peak was judged to be iodinated insulin from its $R_{f}$ value. The second peak was identified as inorganic iodine from the elution pattern 
Table 1. Effect of amounts of radioactive iodine and insulin to be labelled on the specific activity and recovery of iodinated insulin before purification.

\begin{tabular}{lrrrrrr}
\hline \hline $\mathrm{Na}^{125} \mathrm{I}(\mathrm{mCi})$ & \multicolumn{3}{c}{0.5} & & \multicolumn{2}{c}{1} \\
\cline { 2 - 4 } \cline { 6 - 7 } Insulin $(\mu \mathrm{g})$ & 1 & 3 & 4 & & 4 & 5 \\
$\begin{array}{c}\text { Specific activity } \\
(\mu \mathrm{Ci} / \mu \mathrm{g})\end{array}$ & 334 & 120 & 90 & & 200 & 110 \\
$\begin{array}{c}\text { Recovery of } \\
\quad{ }^{125} \mathrm{I}-\mathrm{insulin}(\%)\end{array}$ & 1.3 & 41 & 48 & & 50 & 46 \\
\hline
\end{tabular}

The recovery of insulin is a ratio of the eluted to the total protein-incorporated radioactivity.

of $\mathrm{Na}^{125} \mathrm{I}$ on a column of the same size. No aggregation was seen on gel filtration. After purification on a cellulose column, $10 \%$ trichloroacetic acid (TCA) precipitated $95 \%$ of the radioactivity. Upon acrylamide gel electrophoresis, the radioactivity of purified iodinated insulin formed a single peak (relative mobility, $\mathrm{Rm}=0.80$ ) migrating ahead of native insulin $(\mathrm{Rm}=0.75)$ toward the anode (Fig. 2). When unpurified iodinated insulin was used, a small amount of radioactivity was seen ahead $(\mathrm{Rm}=0.90)$ of the main peak.

As shown in Fig. 3, there was no significant difference between iodinated and native insulins in stimulating glucose oxidation in isolated fat cells.

Iodinated insulin competed with native insulin in binding to mouse mammary epithelial cells (Fig. 4). Cells from early pregnant mice (days 0 to 3 ) show $2680 \pm$ $110 \mathrm{cpm}$ (mean $\pm \mathrm{SE}$ ) of specific binding and $283 \pm 31 \mathrm{cpm}$ of nonspecific binding in 7 experiments. One half of the specific binding was displaced by $10.8 \pm 0.6 \mathrm{ng} / \mathrm{ml}$ of native insulin. When early lactating mice (days 3 to 4 ) were used, amounts of specific and nonspecific binding were 3130 $\pm 102 \mathrm{cpm}$ and $306 \pm 50 \mathrm{cpm}$, respectively, in 5 experiments. Half-displacement was accomplished with $55.7 \pm 9.7 \mathrm{ng} / \mathrm{m} l$ of insulin.

Insulin degradation during incubation was investigated by TCA precipitation and rebinding to fresh mammary cells. The

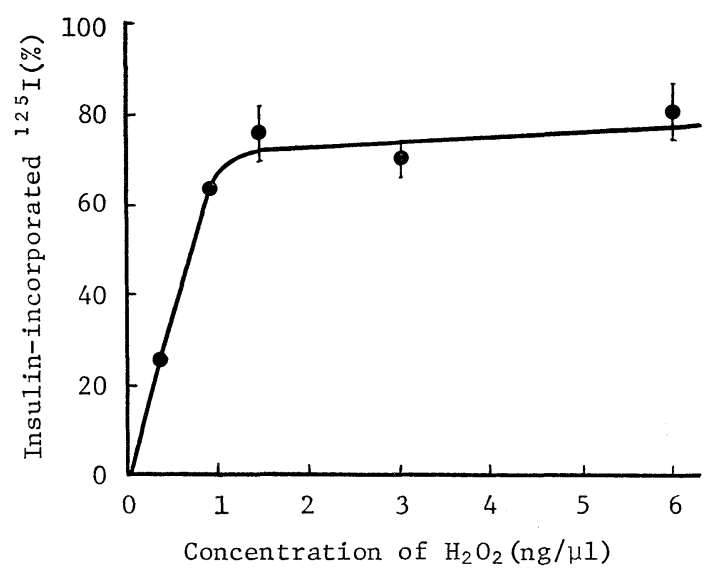

Fig. 1. Effect of hydrogen peroxide concentration on the percentage of radioactivity incorporated into insulin. Bovine insulin $(4 \mu \mathrm{g}$ in $8 \mu l)$ was added to $1 \mathrm{mCi} \mathrm{Na}^{125} \mathrm{I}$ followed by the addition of $10 \mu \mathrm{g}$ lactoperoxidase $(10 \mu l)$. Then $10 \mu l \mathrm{H}_{2} \mathrm{O}_{2}$ at the concentration shown above was added to the mixture four times, totalling $40 \mu l$.

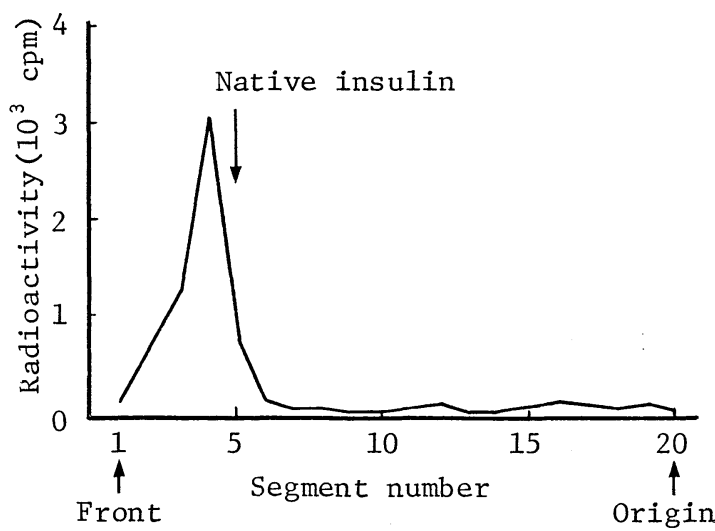

Fig. 2. Distribution of radioactivity on acrylamide gel. Bovine insulin $(4 \mu \mathrm{g})$ was iodinated with $1 \mathrm{mCi} \mathrm{Na}{ }^{125} \mathrm{I}$ by $10 \mu \mathrm{g}$ lactoperoxidase and $60 \mathrm{ng}$ $\mathrm{H}_{2} \mathrm{O}_{2}$. Hydrogen peroxide was added four times (15 ng each). Iodinated insulin was separated on a Sephadex G-50 column $(1 \times 18 \mathrm{~cm})$ from inorganic iodine. The eluate was further purified on a cellulose column (Whatman CF-11). An aliquot of purifed iodinated insulin $(8000 \mathrm{cpm})$ was subjected to $10 \%$ acrylamide gel electrophoresis. The radioactivity of $2-\mathrm{mm}$ gel segments is shown. Note the absence of radioactivity in segments other than the main peak. 


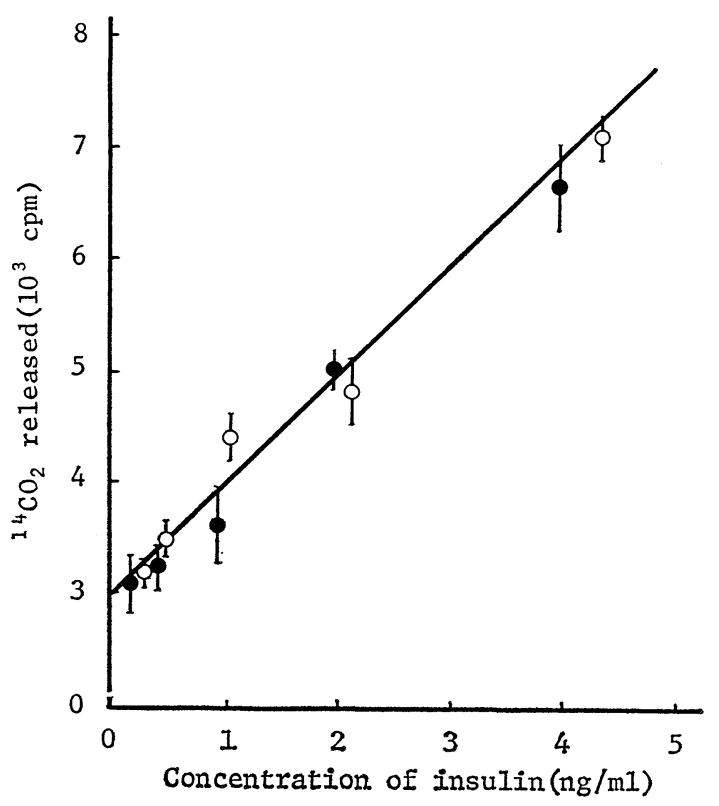

Fig. 3. Stimulation of glucose oxidation in fat cells by native and iodinated insulin. Fat cells $\left(2 \times 10^{5}\right)$ were incubated in $\mathrm{KRB}$ for $2 \mathrm{hr}$ with ${ }^{14} \mathrm{C}$-glucose and native $(\bullet)$ or iodinated $(O)$ insulin. Released ${ }^{14} \mathrm{CO}_{2}$ was trapped in Hyamine-10X and measured. The concentrations of iodinated insulin were calculated from the specific activity. Dose-response curves are identical for both types of insulin.
TCA precipitability in the medium incubated with mammary cells for 30 min was $88 \%$ of that in the fresh control medium. After 30-min incubation with mammary cells, the medium was reincubated with fresh mammary cells for another $30 \mathrm{~min}$. The specific binding of insulin in the incubated medium decreased to $89 \%$ of that in a fresh medium.

The specific binding of iodinated insulin to cells from pregnant mice in the presence of ACTH, prolactin, glucagon, secretin, EGF and NGF was 94, 95, 99, 93, 77 and $81 \%$ of that without these hormones, respectively, and that with cells from a lactating mouse was 96, 98, 100, 98, 97 and $79 \%$, respectively. The specific binding to lactating mammary cells decreased to $90 \%$ when pancreozymin was added to the incubation.

\section{Discussion}

A characteristic of our method of iodination is slow addition of a low concentration of hydrogen peroxide in contrast to the method of Thorell and Johansson (1971) in which the authors used about 20 times

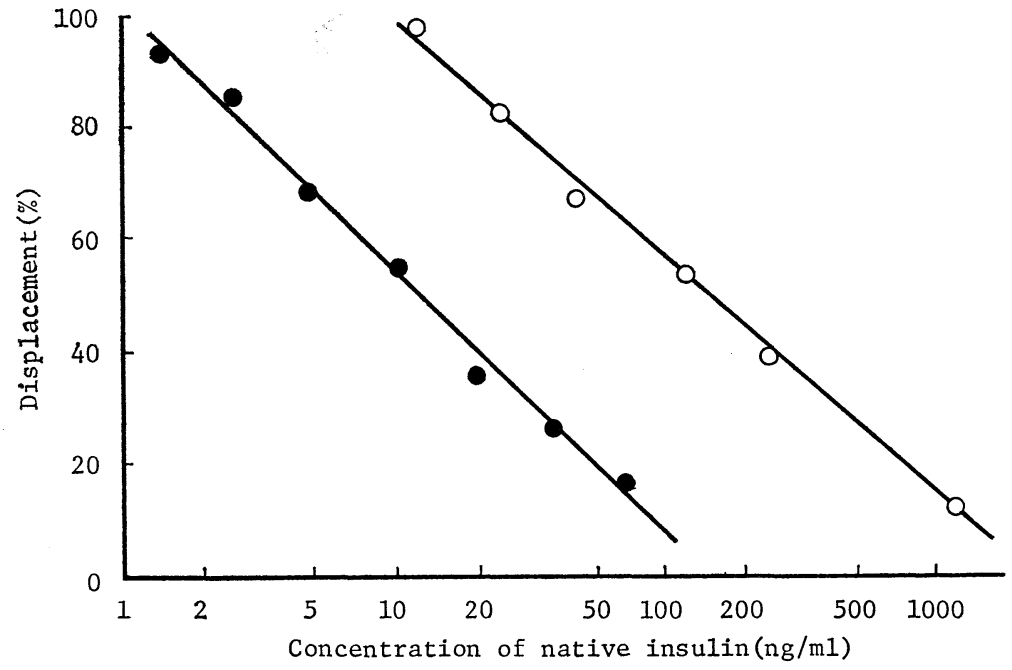

Fig. 4. Displacement of specific iodoinsulin binding by native insulin. Smaller amounts of native insulin displaced the specific binding of iodoinsulin to mammary cells from pregnant mice than to those from lactating mice $(O)$. 
more concentrated hydrogen peroxide and terminated the reaction in $1-2$ or $60 \mathrm{sec}$. Our method may diminish the damage to insulin, giving the hormone a lower risk of exposure to hydrogen peroxide. Iodinated insulin had high specific activity $(180 \mu \mathrm{Ci} /$ $\mu \mathrm{g}$ ), and retained biological potency unimpaired as judged by glucose oxidation in fat cells. Paper chromatography showed that the purified iodinated insulin was mostly composed of monoiodoinsulin. Purification of iodinated insulin on a cellulose column (Freychet et al., 1972) requires no special facility nor time-consuming processes, and is, therefore, useful for small amounts of iodoinsulin, being easier and faster than DEAE chromatography (Freychet et al., 1971; Hamlin and Arquilla, 1974) or long-gel electrophoresis (Linde and Hansen, 1974). Monoiodoinsulin labelled by the chloramine$\mathrm{T}$ method is reported to have high bioactivity and high binding activity to insulin receptors (Freychet et al., 1971). A14 tyrosine-monoiodoinsulin, which is the major product $(75 \%)$ of lactoperoxidase iodination (Hamlin and Arquilla, 1974), is known to maintain its entire bioactivity whereas A19or B-iodinated insulin has lower bioactivity (Gliemann et al., 1979). Linde and Hansen (1974) separated iodoinsulins into 5 bands (uniodinated insulin, A19- or Bmonoiodoinsulin, A14-monoiodoinsulin, diiodoinsulin and triiodoinsulin) on acrylamide gel electrophoresis using long columns. The small amount of radioactivity observed ahead $(\mathrm{Rm}=0.90)$ of the main peak on electrophoresis of unpurified iodinated insulin seems to represent diiodoinsulin, evidence to support the inference that diiodoinsulin was removed by purification on a cellulose column.

Our iodoinsulin had high binding activity to dissociated mouse mammary cells, which was specific and saturable. The amount of nonspecific binding was less than $10 \%$ of that of total binding, probably owing to both good iodoinsulin and undamaged mammary cells. Mammary epithelial cells dissociated by the method used are known to grow in vitro on floating collagen gels (Emerman et al., 1977) and to retain specific prolactin receptors (Sakai et al., 1978). The amount of specific binding to cells from lactating mice was higher than to cells from pregnant mice, suggesting a difference in the number of insulin receptors per cell. Low concentrations of native insulin displaced the specific binding of iodoinsulin. However, displacement curves for pregnant mice were different from those for lactating mice. The displacement of half the amount of specific binding to pregnant cells with a smaller concentration of native insulin than that needed for lactating cells suggests a difference in the affinity of insulin-receptor binding between pregnancy and lactation. The difference was also suggested by the Scatchard plot (Fig. 5). A greater number

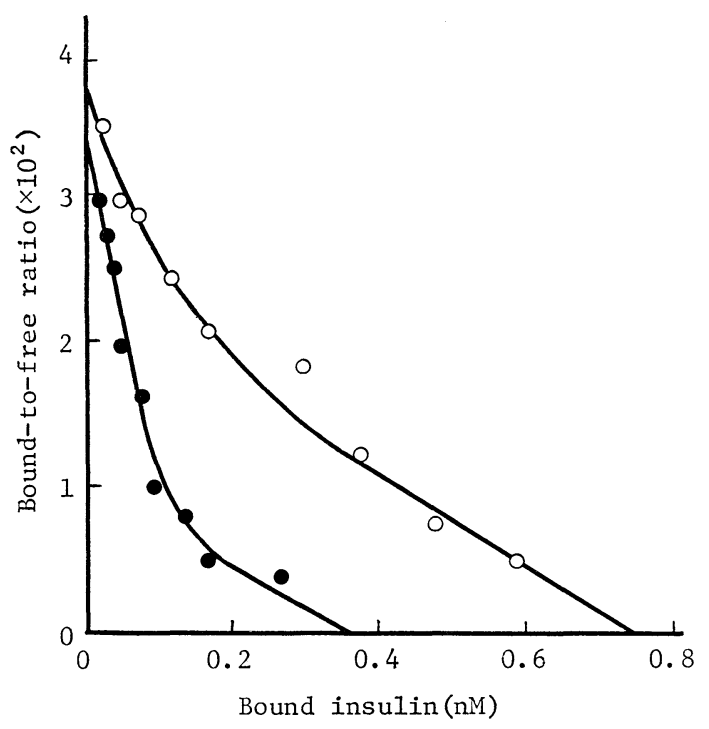

Fig. 5. Scatchard plot for insulin-receptor binding. Mammary cells from pregnant (O) and lactating (O) mice were incubated for $45 \mathrm{~min}$ at room temperature in M199 with iodinated insulin purified on a cellulose column. After cells were washed with phosphosaline, the radioactivity bound to cells was counted. The bound-to-free ratio was plotted vs. bound insulin. 
of binding sites in lactating mammary cells than in pregnant cells has been reported with no obvious change in affinity (O'Keefe and Cuatrecasas, 1974). The change in the affinity of binding may be resulted from the presence of heterogeneous insulin receptors with different affinity (Krupp and Livingston, 1980), or by a negative cooperative type of site-site interaction as observed by Kahn et al. (1978) in liver plasma membranes at different glucocorticoid levels. The property of insulin binding to dissociated cells from mice in various stages of mammary development is now under investigation using the iodoinsulin described herein.

\section{Acknowledgements}

We wish to thank Dr. Masato Kasuga, Departmet of Internal Medicine, University of Tokyo School of Medicine, and Dr. Jumpei Enami, Department of Physiology, Dokkyo University School of Medicine, for providing information on glucose oxidation assays and on mammary cell dissociation, respectively, and Dr. Toshio Harigaya for his help with lactoperoxidase iodination. EGF and NGF are gifts from Dr. Kyozo Hayashi, Associate Professor of Biological Chemistry, Faculty of Pharmaceutical Sciences, Kyoto University. This work is supported in part by Grants-in-Aid for Cancer Research from the Ministry of Education, Science and Culture of Japan (301082 and 401086).

\section{References}

Apostolova, J., L. M. Sirakov and T. Barth (1976). Insulin receptors in lactating mouse mammary gland. Collect. Czechoslov. Chem. Commun. 41, 3830-3836.

DeMeyts, P., A. R. Bianco and J. Roth (1976). Sitesite interactions among insulin receptors. Characterization of the negative cooperativity. J. Biol. Chem. 251, 1877-1888.

Emerman, J. T., J. Enami, D. R. Pitelka and S. Nandi (1977). Hormonal effects on intracellular and secreted casein in cultures of mouse mammary epithelial cells on floating collagen membranes: Proc. Natl. Acad. Sci. U.S.A. 74, 4466-4470.

Enami, J., S. Nandi and S. Haslam (1973). Production of three dimentional structures-"domes"- from dissociated mammary epithelial cells of mice. In Vitro 8, 405.

Freychet, P., C. R. Kahn, J. Roth and D. M. Neville, Jr. (1972). Insulin interactions with liver plasma membranes. Independence of binding of the hormone and its degradation. J. Biol. Chem. 247, 3953-3961.

Freychet, P., J. Roth and D. M. Neville, Jr. (1971). Monoiodoinsulin: Demonstration of its biological activity and binding to fat cells and liver membranes. Biochem. Biophys. Res. Commun. 43, 400408 .

Gliemann, J., O. Sonne, S. Linde and B. Hansen (1979). Biological potency and binding affinity of monoiodoinsulin with iodine in tyrosine A14 or tyrosine A19. Biochem. Biophys. Res. Commun. 87, 1183-1190.

Greenwood, F. C., W. M. Hunter and J. S. Glover (1963). The preparation of $131 \mathrm{I}$-labelled human growth hormone of high specific radioactivity. Biochem. J. 89, 114-123.

Hamlin, J. L. and E. R. Arquilla (1974). Monoiodoinsulin. Preparation, purification, and characterization of a biologically active derivative substituted predominantly on tyrosine A14. J. Biol. Chem. 249, 21-32.

Harmon, J. L. and R. Hilf (1976). Identification and characterization of the insulin receptor in the R3230AC mammary adenocarcinoma of the rat. Cancer Res. 36, 3993-4000.

Juergens, W. G., F. E. Stockdale, Y. J. Topper and J. J. Elias (1965). Hormone-dependent differentiation of mammary gland in vitro. Proc. Natl. Acad. Sci. U.S.A. 54, 629-634.

Kabuto, M., K. Suzuki, N. Ohsawa and K. Kosaka (1977). A radioreceptor assay for insulin: Direct measurement of dog pancreatic vein serum insulin. Endocrinol. Japon. 24, 173-178.

Kahn, C. R., I. D. Goldfine, D. M. Neville, Jr. and P. DeMeyts (1978). Alterations in insulin binding induced by changes in vivo in the levels of glucocorticoids and growth hormone. Endocrinology 103, 1054-1066.

Kasuga, M., Y. Akanuma, Y. Iwamoto and K. Kosaka (1977). Effects of fasting and refeeding on insulin receptors and glucose metabolism in rat adipocytes. Endocrinology 100, 1384-1390.

Krupp, M. N. and J. N. Livingston (1980). The binding and degradation of insulin by rat liver membranes: Demonstration of three distinct insulin-binding components in detergent-solubilized material from liver plasma membrane. Endocino$\log y$ 106, 179-184.

Linde, S. and B. Hansen (1974). Preparation and characterization of monoiodoinsulin. Intl. J. Peptide Protein Res. 6, 157-163.

O'Keefe, E. and P. Cuatrecasas (1974). Insulin receptors in murine mammary cells : Comparison in pregnant and nonpregnant animals. Biochim. Bio- 
phys. Acta 343, 64-77.

Rodbell, M. (1964). Metabolism of isolated fat cells. I. Effects of hormones on glucose metabolism and lipolysis. J. Biol. Chem. 239, 375-360.

Sakai, S., K. Kohmoto and T. Johke (1975). A receptor site for prolactin in lactating mouse mammary tissues. Endocrinol. Japon. 22, 379-387.
Sakai, S., J. Enami, S. Nandi and M. R. Banerjee (1978). Prolactin receptor on dissociated mammary epithelial cells at different stages of development. Mol. Cell. Endocrinol. 12, 285-298.

Thorell, J. I. and B. G. Johansson (1971). Enzymatic iodination of polypeptides with ${ }^{125}$ I to high specific activity. Biochim. Biophys. Acta 251, 363-369. 